\title{
The Civilizational Limits of Citizenship
}

The 1792 issue of the Historiesch schouwtooneel van 's waerelds lotgevallen (Historical Theatre of the World's Vicissitudes), a respected Dutch spectatorial magazine on international affairs, enthusiastically welcomed the French Legislative's Assembly's decision of 15 May 1791 to extend full citizenship to free men of colour born of free parents. ${ }^{1}$ Once the decree had reached SaintDomingue, the Historiesch schouwtooneel reported, 'all classes of free inhabitants' gathered to celebrate the 'federation-feast' of July 14. 'Whites, Mulattoes, free negroes, National Guards, troops of the line', all joined together to rescue the northern district from the 'insurgent negroes' whom the magazine depicted as 'rebels'. While the magazine cheered 'the much-needed reconciliation of whites and people of colour', the extension of citizenship to black rebels seemed out of the question. ${ }^{2}$

The image of Saint-Dominguan whites and free people of colour brotherly celebrating July 14th, however, was soon substituted for 'scenes of destruction, murder, arsons, in one word, civil war', as the Batavian Revolution's most influential writer and founding father Pieter Paulus put it in his famous 1793 Treatise on Equality. ${ }^{3}$ The leading Orangist publicist Adriaan Kluit, an outspoken ideological opponent of Paulus and a fierce critic of his compatriot admirers of French revolutionary ideas, similarly wrote of the islands' 'catastrophic and miserable state. ${ }^{4}$ Kluit imputed the catastrophe of Saint-Domingue to French 'foolishness'. They had 'introduced there [Saint-Domingue] mistaken doctrines of liberty $[\ldots]$ and principles under the guise of lovely appearances', he fulminated, 'and endeavoured to let impracticable maxims of a reckless Patriotism

1 For 'respected' see the review in Vaderlandsche Letteroefeningen (1793), vol. 1, p. 488. http:// www.dbnl.org/tekst/_vadoo3179301_01/_vadoo3179301_01_0141.php. Date of access: 11-7-2013.

2 Historiesch schouwtooneelvan 's waerelds lotgevallen; in het jaar 1792, 4 vols. (Haarlem: Loosjes, 1792), vol. 3, pp. 397-400.

3 Paulus, Verhandeling, p. 207.

4 [Adriaan Kluit], De rechten van den mensch in Vrankrijk, geen gewaande rechten in Nederland. Of Betoog, dat die rechten bij het volk van Nederland in volle kracht genoten worden en iets over onze vrijheid en patriotismus. Door een patriot [The Rights of Man in France, No Pretended Rights in The Netherlands, or Demonstration that those Tights are enjoyed to the Full Extent by the People of The Netherlands; and Something about our Liberty and Patriotism. By a Patriot] (Amsterdam: W. Brave, 1793), p. 50. 
apply'. ${ }^{5}$ Such dire images of Saint-Domingue would come to haunt the minds of Dutch politicians, thinkers and journalists for years to come.

Between 1790 and 1793, several Dutch newspapers reported on the island's 'revolt', the 'fermentations' and the 'skirmishes'. ${ }^{6}$ But Paulus and Kluit were the first two prominent Dutch opinion makers of the early 179os who devoted serious attention to the slave uprising. The insurrection broke out in August 1791 in Saint-Domingue's Northern Province, a few miles outside of the port city of Cap Français. Within a few months a growing group of black insurrectionists were able to take control of most parts of the Northern Plain. Hundreds of coffee and sugar plantations were attacked and set to flames, many white plantation owners and their families killed. Almost simultaneously an army of free coloured people rose in the island's west province where white landowners were eventually forced to accede to their demands of admission to local representative assemblies.

The news of the insurrection reached Paris in late October. It incited turbulent debates both inside and outside the Legislative Assembly about the question who was responsible for what was widely considered a deeply troubling situation. As important was the question how it could be suppressed. An extra complicating factor was that on 24 September, one month before the news of the insurrection would reach Paris, the National Assembly had reversed the 15 May decree granting people of colour (born of free parents) citizenship. It only enhanced the impression that the metropole's policy was oscillating and confused. After months of vehement disagreement and mutual recriminations, members of the Société des Amis des Noirs, Brissot most prominently, pushed the Legislative Assembly to grant all free people of colour equal citizenship rights. Only by uniting white and free coloured citizens, they argued, order could be restored. The law was signed by King Louis XVI on April 4, 1792. A (second) Civil Commission led by Étienne Polverel and Léger-Félicité Sonthonax, two Jacobins who had earlier opposed slavery in writing, was instructed to enforce the controversial law and put down the slave insurrection with the help of 6,ooo troops. The Civil Commission forged alliances with various groups of free people of colour, but were unable to restore order, as they faced recalcitrant whites allying with British forces and black insurgents allying with Spanish forces from Santo Domingo. Not surprisingly, the leadership of the

5 [Kluit], De rechten van den mensch in Vrankrijk, geen gewaande rechten in Nederland, p. 50.

6 Groninger courant, 9 March 1789, 15 October 1790, 27 August 1793; Oprechte Haerlemsche courant, 8 November 1791; Ommelander courant 30 November 1792, 30 July 1793; Rotterdamse courant, 27 July 1793 . 
black insurgents distrusted the French and were not willing to give up their position.

In June 1793, the situation on the island toppled when the Civil Commissioners summoned the help of black insurgents to fight as free soldiers of the French Republic against white troops in Cap Français. In the chaos of subsequent fighting, as white soldiers were fleeing to their ships, the wealthiest European colonial city of the Caribbean went up in flames. By late August 1793, Sonthonax and Polverel became convinced that only a general emancipation decree could win the black insurgent armies over to their side. First in the North, on August 29, and in the South and the West the following months, the Civil Commissioners decreed that all former slaves would enjoy 'all the rights of French citizens. ${ }^{7}$ In doing so, they revolutionized the social and racial hierarchy on the island for good.

Paulus's and Kluit's interpretations of the 1791 uprising point to two issues concerning the insurrection that throughout the 1790 s would be subject to conflicting interpretations and representations: what was the nature of this insurrection and the insurrectionists involved in it? And what had caused it? Paulus attributed the slave insurrection and civil war to the 'rash' French decision to suddenly liberate the 'entire' enslaved black population. Of course, as human beings, Paulus argued, 'the African people' have the same rights as Europeans. But giving them equal rights and liberties must be done 'gradually', as the 'fatal consequences' of revolutionary France's 'abrupt' liberation policy conclusively demonstrated. What is most intriguing about Paulus' publication and his claim about French imperial policies is that they actually preceded the emancipation decrees of the Civil Commissioners on Saint-Domingue of June 1793 and their ratification by the French National Convention in February 1794. His factually incorrect explanation tells us a lot about how the (admittedly very complex) relationship between a French radical ideology and the events in Saint-Domingue was perceived and represented at the time.

Historians have rightly pointed out that over the course of the nineteenth century 'competing narratives' of the slave insurrection emerged. But during the 1790 s and early nineteenth century the images drawn of the insurgency were predominantly dismal and horrific. ${ }^{8}$ The terms used by American, Dutch,

7 Dubois, Avengers of the New World, pp. 162-164.

8 Rugemer, The Problem of Emancipation, esp. Ch. 2. More generally, see Hunt, Haiti's Influence on Antebellum America; White, Encountering Revolution; Clavin, Toussaint Louverture and the American Civil War; J.D. Popkin, Facing Racial Revolution: Eyewitness Accounts of the Haitian 
and French commentators to describe the overall condition of Saint-Domingue in the years following the insurrection, such as 'anarchy' and 'wilderness', as well as the portrayal of black insurgents as uncontrollable, disorderly savages, with 'fiery' characters, taken over by 'relentless rage' and accustomed to 'African barbarism', functioned within a crude framework of 'civilized' and 'uncivilized' peoples. ${ }^{9}$ A crucially important and dominant line of response to the slave insurrection, although not the only one, consisted of the depiction of the revolting black slaves as uncivilized savages.

While the earlier stages of the Haitian Revolution in which white planters and free people of colour were involved had put the notion of national citizenship to the test, as their struggles had expanded the scope of national citizenship to the empire's colonies, the insurrection of black slaves raised yet other questions. Initially, these questions concerned responsibility for the insurrection and strategies for its containment, not whether black slaves too were to become citizens. Hardly anyone in revolutionary France - including the members of the Société des Amis des Noirs - was in favour of immediate emancipation. Those who supported equal citizenship rights for free people of colour instead underlined the constitutional unity of the French empire, the sovereignty of the nation's main representative body, and the soundness of the metropole's interventionist strategy. What they also reasserted was the civilizational hierarchy within the empire and the civic subordination of those who were deemed insufficiently enlightened. The Enlightenment language of the progress - and backwardness - of civilizations provided a mode to distinguish between legitimate claims for civic equality and what were considered violent and barbaric spasms of an illegitimate frenzy.

More conservative responses to this new phase of the Haitian Revolution emphasized the supposed lethal combination of, on the one hand, the primitive and savage nature of black slaves and, on the other hand, the extension of the principles of freedom and equality as enshrined in declarations of the rights of man. According to such interpretations, the savagery and destruction they associated with the insurrection proved that black slaves were insufficiently civilized to adopt the rights and duties of citizenship. To many Americans and Dutchmen, it proved that the French revolutionary ideology had spiralled out of control.

Insurrection (Chicago, IL: University of Chicago Press, 2007); Geggus (ed.), The Impact of the Haitian Revolution in the Atlantic World.

9 Cf. Hunt, Haiti's Influence on Antebellum America, pp. 20-22; White, Encountering Revolution, pp. 3,57 . 
The notion of a certain people's or social group's stage of civilization was more central to the demarcation of the limits of citizenship in 179os than is sometimes recognized. The rough distinction between civilized and uncivilized was part and parcel of what could be called a family of eighteenth-century theories of historical progress. Common to such 'philosophical histories' is that they conceive of history as the unfolding of a linear universal process. Within this unfolding process, several stages of development can be distinguished, each successive stage displaying a change in manners, laws, technology, customs, and morals. ${ }^{10}$

Although an Enlightenment thinker such as the mid-eighteenth-century French historian Antoine-Yves Goguet in his $175^{8}$ De l'Origine des Loix, des Arts, et des Sciences: et de leurs progrès chez les anciens peuples only differentiated roughly between two stages, other theorists, notably Anne-Robert-Jacques Turgot and Adam Smith, centring their approach on means of subsistence and societal relations, distinguished three or more stages in history: the earliest stage of hunter-gatherers, followed by a second pastoral stage; a third stage characterized by agriculture, and a fourth, final stage of commercial society, the most advanced stage. ${ }^{11}$ Other Enlightenment thinkers such as the Scottish historian William Robertson and the French philosophe and revolutionary Condorcet, while employing a similar language of stages distinguished by modes of subsistence, shifted the focus to what Jennifer Pitts has called the 'cognitive-development conception of progress.' ${ }^{12}$ Within this conception, history essentially displays, as Condorcet put it, 'the progress of the human mind'. According to such theories, people living in an early, primitive stage of society were, quite literally, mentally and morally 'infantile', comparable to children. 'In the early stages of society', William Robertson explained, 'while

10 Harvey, The French Enlightenment and its Others; Sebastiani, The Scottish Enlightenment; S. Stuurman, The Invention of Humanity. Equality and Cultural Difference in World History (Cambridge, MA: Harvard University Press, 2017); Whelan, Enlightenment Political Thought and Non-Western Societies.

11 For Goguet, see J.G.A. Pocock, Barbarism and Religion, 6 vols. (Cambridge: Cambridge University Press, 2001-2015), vol. 4: Barbarians, Savages and Empires, Ch. 3; N. Wolloch, "Facts, or Conjectures": Antoine-Yves Goguet's Historiography', Journal of the History of Ideas 68 (2007), pp. 429-449. On the four stages theory generally, see Meek, Social Science and the Ignoble Savage; Hont, 'The Language of Sociability and Commerce'. Technically speaking, Smith did not distinguish a fourth 'commercial' stage, since all stages evinced some level of commercial activity.

12 J. Pitts, 'Empire, Progress, and the "Savage Mind", in: J.T. Levy and I.M. Young (eds.) Colonialism and its Legacies (Lanham, MD: Lexington Books, 2011), pp. 21-52. 
the condition of man is simple and rude, his reason is but little exercised. ${ }^{13}$ Fundamental to such histories of the human mind is that the degree of enlightenment of the mind of a single human being paralleled the state of civilizational progress. Goguet's history of civilization was essentially governed by the same principle: "The history of laws, arts, and sciences, is, properly speaking, the history of the human mind. ${ }^{14}$ Whereas there was a well-established although not uncontradictory - French tradition of writing about 'noble savagery', stretching from Montaigne to Lahontan and Rousseau, Goguet's picture of the savage man, purportedly drawn on traveller's accounts, was anything but noble. Their character was 'cruel and ferocious' and they live in perpetual war [...] void of all the principles of humanity, without laws, polity, or government'. ${ }^{15}$ Although not always as vicious as Goguet's depiction, the distinction between civilized and uncivilized people had become a fairly uncontested element in the worldview of most Dutchmen and Frenchmen by the end of the eighteenth century. It is, indeed, remarkable how profoundly this understanding of inequalities in civilizational progress had taken root among broad sections of the public within only a few decades.

In the United States too, theories of progress and 'environmentalism', that is, the view that differences between civilizations, peoples, and races could be explained by environmental factors and stages of progress, were widely accepted, at least until the 179os. An hugely influential and particularly representative example of this kind of thinking is An Essay on the Causes of the Variety of Complexion and Figure in the human Species (1787) by the professor of moral philosophy at New Jersey College (renamed into Princeton University in 1896), Samuel Stanhope Smith. ${ }^{16}$ Departing from the proposition that 'mankind is a single species', Smith explained that 'by the state of society many varieties in the human person are formed'. The state of society, comprising 'diet, clothing, lodging, habits, face of the country, objects of science, religion,

13 W. Robertson, History of America, 2 vols. (Dublin: Whitestone, 1777), vol. 1, p. 308. Robertson's History of America was translated both into Dutch and French as early as 1778. A new and augmented French translation was published in Amsterdam in 1779 and again in 1789 . On Robertson and his reception, see S.J. Brown (ed.) William Robertson and the Expansion of Empire (Cambridge: Cambridge University Press, 2008).

14 As cited in: Pocock, Barbarians, Savages and Empires, p. 44.

15 Ibid, p. 46.

16 S. Stanhope Smith, An Essay on the Causes of the Variety of Complexion and Figure in the Human Species: To which are added Strictures on Lord Kaims's Discourse, on the Original Diversity of Mankind (Philadelphia, PA: R. Aitken, 1787). An enlarged and revised edition appeared in 1810. On Smith, see Dain, Hideous Monster of the Mind:American Race Theory in the Early Republic (Cambridge, MA: Harvard University Press, 2002), pp. 41-80; Guyatt, Bind Us Apart, pp. 61-63. 
interests, passions and ideas of all kind, infinite in number and variety', were the parameters that determine if a people live in a 'savage state' or in a 'state of civilization'. While Stanhope Smith deemed the 'progress of civilization' to be rather slow, he highlighted the 'immense [...] difference between the manners of Europe barbarous, and of Europe civilized. ${ }^{17}$ On this basis, he had no doubt that the 'emancipation of the African race in the United States [...] must necessarily be the slow and gradual work of time'.18

Arguably, drawing such distinctions between civilized and uncivilized peoples within a universal linear historical framework, as well as self-consciously identifying oneself as 'enlightened', were central aspects of an eighteenthcentury process of Western European and North-American intellectual and cultural identity formation. 'More than anything', Dan Edelstein acutely observed, 'the Enlightenment seems to have been the period when people thought they were living in an age of Enlightenment. ${ }^{\prime 9}$ But Enlightenment views on 'philosophical history' were not merely innocent modes of European reflexive self-understanding and self-description. They helped to establish a 'modern' discourse of inequality: the unavoidability of historical progress and historical backwardness - as expounded in such theories, brought about what Siep Stuurman calls a 'powerful inequality effect'. ${ }^{20}$

Philosophical theories of civilizational and cognitive progress (and backwardness) gained a pertinent political relevance in responses to the 'disaster' of Saint-Domingue. This discourse 'politicized' as the Haitian Revolution expanded the revolutionary agenda. ${ }^{21}$ Put differently, eighteenth-century schemas of civilizational inequality based on Enlightenment theories of historical progress culminated in responses to the Haitian Revolution and in debates concerning the limits of modern republican citizenship for black SaintDominguan insurrectionists. The reception of the Haitian Revolution, thus,

17 Smith, An Essay, pp. 44, 62-63, 86-87.

18 S. Stanhope Smith, 'On the Relation between Master and Servant', in: idem, Lecture... on Subjects of Moral and Political Philosophy, 2 vols. (Trenton, N.J.: Daniel Fenton, 1812), vol. 2, pp. 159-179, at p. 173 .

19 D. Edelstein, The Enlightenment: A Genealogy (Chicago, IL: University of Chicago Press, 2010), p. 73 .

20 Stuurman, The Invention of Humanity, p. 16. See also, J. Pitts, A Turn to Empire: The Rise of Imperial Liberalism in Britain and France (Princeton, N.J.: Princeton University Press, 2005).

21 Cf. T. Kaiser and D. van Kley, 'Introduction' and 'Conclusion' in: Kaiser and Van Kley (eds.), From Deficit to Deluge. For the political connotation that the word civilization took on, see P. Michel, 'Barbarie, Civilisation, Vandalisme', in: Reichardt and Schmitt (eds.) Handbuch Politisch-Sozialer Grundbegriffe, pp. 7-50. For a Dutch perspective, see Sens, 'Mensaap, heiden, slaaf'. 
provides a focal point where the language of the rights of man and the language of philosophical theories of historical progress clashed, were reconciled, and reconfigured. If the Haitian Revolution was a key-moment in the history of the universalization of rights, it was also a key-moment in the erection of argumentative walls against the universalization of rights.

The justifications for denying black slaves equal citizenship during the $1790 \mathrm{~s}$ put forth by contemporary observers in the Atlantic world drew much heavier upon Enlightenment theories of civilizational progress - and backwardness than has been recognized in the existing historiography. Laurent Dubois has qualified the ways in which colonial authorities excluded black slaves and ex-slaves from citizenship as 'republican racism..$^{22}$ But this way of describing the arguments endorsing exclusion does not capture the intellectual assumptions behind them: arguments for exclusion were not specifically or exclusively 'republican' in nature. Under Napoleonic authoritarianism and under nineteenth-century constitutional monarchies arguments based on civilizational backwardness for civic exclusion - and arguments in favour of a mission civilisatrice - were employed on a wide scale. ${ }^{23}$

Moreover, the 1790s discourse of civic exclusion that was applied to free and enslaved black people was by and large not strictly racist, at least not in the way that 'racism' developed as a more or less coherent body of (biological and scientific) thought in the nineteenth century. Of course, the discourse of civilization and historical progress was not the only available language to explain human diversity in the second half of the eighteenth century. As an everexpanding body of scholarship has established, Enlightenment theories of racial classification positing new hierarchical orderings increasingly gained ground in the second half of the eighteenth century. ${ }^{24}$ These theories were generally not based on a deep, biological conception of racial difference. Polygenism (the view that humanity had different progenitors) was advocated by some, if rather speculatively. ${ }^{25}$ Most people in the second half of the

22 Dubois, Colony of Citizens, p. 3; cf. L. Dubois, 'Republican Antiracism and Racism: A Caribbean Genealogy', French Politics, Culture \& Society 18 (2000), pp. 5-17.

23 A.L. Conklin, A Mission to Civilize: The Republican Idea of Empire in France and West Africa, 1895-1930 (Stanford, CA: Stanford University Press, 1997).

24 F. Bethencourt, Racisms. From the Crusades to the Twentieth Century (Princeton, N.J.: Princeton University Press, 2013); J.E.H. Smith, Nature, Human Nature \& Human Difference. Race in Early Modern Philosophy (Princeton, N.J.: Princeton University Press, 2015); Stuurman, The Invention of Equality, pp. 301-316.

25 The most prominent eighteenth-century polygenists, although varying in degrees of sophistication, were Lord Kames (Henry Home), Cornelius de Pauw, David Hume, and Voltaire. It would be a mistake, however, to simply equate polygenism with a pro-slavery stance (or, conversely, monogenism with an antislavery stance). See Curran, The Anatomy 
eighteenth century were hesitant to accept the idea that races were essentially different from each other. One important reason is that it seemed to contradict God's single creation and humanity's shared descent from common ancestors as told in Scripture. ${ }^{26}$ The French naturalist Georges-Louis Leclerc, count of Buffon (1707-1788) and the German anatomist, anthropologist, and professor of medicine, Johann Friedrich Blumenbach (1752-1840), arguably the two most influential eighteenth-century theorists of racial difference, defended the unity of the human species against polygenism. Whereas histories of civilizational progress studied the history of man in society (civic history), Buffon and Blumenbach studied man as part of the natural world. They explained the variety of the human species by considering nature 'in the succession of time', thus writing a 'natural history' of humanity's physical and cultural diversity in which climate and the environment were the overarching explanatory factors. ${ }^{27}$

Recent scholarship has taught us that there was no clear-cut division or opposition between eighteenth-century philosophical histories of civilizational progress and natural histories of racial difference. ${ }^{28}$ Yet what is crucial to see in relation to how these discourses were invoked and politically mobilized in reactions to the Haitian Revolution, is the default setting both discourses assume. Briefly put, for naturalists such as Buffon and his followers 'whiteness' was the 'global standard'; for philosophical historians such as Condorcet, European enlightened civilization was the universal norm. ${ }^{29}$ As both discourses rejected essentialist biological racism, the difference between the ways in which both discourses conceived of the capability or potential of enslaved Africans of being elevated to the level of (white) enlightened Europeans seems to have been a matter of degree.

of Blackness, pp. 190-199. On the relationship between race, monogenism and Protestant theology, see C. Kidd, The Forging of Races: Race and Scripture in the Protestant Atlantic World, 160o-200o (Cambridge: Cambridge University Press, 2006).

26 Kidd, The Forging of Races.

27 Bethencourt, Racisms, pp. 247-270; Stuurman, The Invention of Humanity, pp. 301-316.

28 Cf. Bruce Dain's remark: 'Racial concepts did not move tidily from a shallow Enlightenment environmentalism to a deep biology; nor were the two positions mutually exclusive. Nurture and nature intertwined. No linear progression led from essentially ethnocentric, superficial Enlightenment egalitarianism to an unequivocal, candid - and politically expedient - nineteenth-century "hard" racism. New work in the history of science teaches us that a sharp distinction between nineteenth-century biology and eighteenth-century natural history is not tenable'. Dain, Hideous Monster of the Mind, vii. On the relationship between natural and philosophical (civil) history, see Sebastiani, The Scottish Enlightenment, pp. 64-71.

'Global standard' is Stuurman's phrase. Stuurman, The Invention of Humanity, p. 306. 
But even if the distinction between natural history and the (civic) history of civilizational progress was not always sharp, during the 1790 s the prevailing scheme of thought was still largely couched in terms of civilizational inequality, progress and backwardness. One important reason why it was so widely invoked in the 1790 s was that it could be used with a certain flexibility. It enabled philosophers, revolutionaries, politicians and publicists on the progressive side of the transatlantic ideological spectrum to subscribe to a future vision in which non-white peoples had the potential to become equal citizens. They could accept civic inequality based on civilizational backwardness since it would only be temporary: it could be overcome. The discourse of civilizational progress accordingly enabled progressive revolutionaries to reconcile their commitment to revolutionary principles of equality with the denial of citizenship to people who were deemed insufficiently civilized. Those with more moderate or conservative views on the expansion of citizenship, as well as reactionary defenders of slavery, sometimes resorted to more biological (essentialist) approaches to racial inferiority. Most prominently, the creole jurist, writer, and representative par excellence of the French 'colonial Enlightenment' Médéric-Louis-Élie Moreau de Saint-Méry, as well as Thomas Jefferson, combined judgments on what they considered the physical and moral depravity of blacks with theories of racial degeneration and anxieties of racial intermixture. ${ }^{30}$ But opponents of emancipation in the Atlantic world also eagerly employed the language of civilizational backwardness, both to postpone the abolition of slavery and to justify their unequal civil status within society.

To be sure, the point is not that the Haitian Revolution as such brought bring into existence or cause the view that black slaves were uncivilized or unenlightened, and hence considered unfit for citizenship. As we have seen, throughout the 1780 s, black citizenship in American non-slaveholding states

30 On Moreau de Saint-Méry, see D. Brion Davis, The Problem of Slavery in the Age of Revolutions (Ithaca, N.Y.: Cornell University Press, 1975), pp. 184-195; J.D. Garrigus, Before Haiti: Race and Citizenship in French Saint-Domingue (New York: Palgrave, 2006), pp. 156-159. On Moreau and the 'colonial Enlightenment', M.W. Ghachem, 'Montesquieu in the Caribbean: The Colonial Enlightenment between Code Noir and Code Civil', in: D. Gordon (ed.) Postmodernism and the Enlightenment: New Perspectives in Eighteenth-Century French Intellectual History (New York: Routledge, 2001), pp. 7-30. On Jefferson, see D.R. Egerton, 'Race and Slavery in the Era of Jefferson', in: F. Shuffleton (ed.) The Cambridge Companion to Thomas Jefferson (Cambridge: Cambridge University Press, 2009), pp. 73-82; W. Jordan, White over Black. American Attitudes toward the Negro, 1550-1812 (Chapel Hill, N.C. University of North Carolina Press, 1968), pp. 429-481; M. Zuckerman, 'The Power of Blackness: Thomas Jefferson and the Revolution in St. Domingue', in: idem, Almost chosen People. Oblique Biographies in the American Grain (Berkeley, CA: California University Press, 1993), pp. 175-219. 
was limited and subject to fierce debates with varying, confused and unstable outcomes. In the most elaborate French antislavery tractate La cause des esclaves nègres (The Cause of Black Slaves), published in 1788, the Lyon Protestant pastor Benjamin Frossard suggested that 'Negroes are still in the infancy of civilization'. Only by teaching them the 'required religious and moral obligations', Frossard held, they could be sufficiently prepared 'to bear the respectable title of citizen.' ${ }^{11}$ Such writings preceded the Haitian Revolution, but many of its assumptions would be reproduced throughout the 1790 .

In the Dutch Republic too, the importance of one's degree of enlightenment so as to qualify for full-fledged citizenship was already fully articulated in 1790 . The Dutch translation of Frossard's text would become one of the most-cited antislavery texts at the time. ${ }^{32}$ In one of the Dutch Republic's most widely read spectatorial magazines of the late 1780 s and early 179os, the Bijdragen tot het menschelijk geluk (Contributions to Human Happiness), the Dutch journalist, remonstrant professor of theology, and prominent future Batavian revolutionary Jan Konijnenburg similarly posited that 'negroes' still resided quite literally in an age of civilizational infancy. He argued that just as 'to our children, the more their knowledge and experience increases, the more freedom we allow them; likewise, the negro who is still in a state of infancy should not be withhold his freedom forever. ${ }^{33}$ Konijnenburg, thus, put forth an exemplary articulation of a gradual expansion of citizenship: 'the stage of freedom' to be allowed to the 'Negroes', 'had to be proportional to their degree of enlightenment and civilization'. 'The more they show themselves' to be educated and 'well-behaved', Konijnenburg argued, the larger 'should be their share in the freedom and rights of the Dutch citizen.' ${ }^{34}$

Likewise, the Dutch radical patriot minister, poet and future politician Bernardus Bosch claimed in 1791 that slavery should be abolished since enslaved black people are our 'fellow human beings'. But again, this should be done gradually. 'Because we are so much more enlightened and civilized than they

31 B. Frossard, La cause des esclaves nègres et des habitants de la Guinée, portée au tribunal de la justice, de la religion, de la politique; ou Histoire de la traite \& de l'esclavage des nègres, preuves de leur illégitimité, moyens de les abolir sans nuire ni aux colonies ni aux colons, 2 vols. (Lyon: Imprimerie d'Aimé de la Roche, 1789), vol. 1, pp. 22-23.

32 B. Frossard, De zaak der negerslaaven, en der inwooneren van Guinéa ...; of, Historie van den handel, en de slavernij der negers; bewijzen van derzelver onwettigheid; middelen om die te vernietigen, zonder de colonien, of de colonisten te benadeelen, 2 vols., trans. E. Wolff-Bekker (The Hague: Isaac van Cleef, 1790).

33 [J. Konijnenburg], 'Proeve eener verhandeling over den slaavenhandel en den aankleeve van dien', Bijdragen tot het menschelijk geluk 4, (1790), pp. 86-87.

34 [Konijnenburg], 'Proeve', p. 84 (italics in original). 
[black people] are, we should rather treat such unhappy creatures with pity, endeavour to enlighten them, and in all kinds of ways promote their happiness'. ${ }^{35}$ Several years later, during the Batavian Revolution, this kind of reasoning could be heard everywhere.

Arguments concerning the 'backwardness' or 'savage state' of certain peoples - and the notion of the potential of their 'regeneration' - were not only applied beyond borders or the colour-line to, for example, free and enslaved Africans, indigenous Javanese or native North American peoples. They were also applied domestically, that is, to Jews, to (white) peasants, the urban poor, and to those who were seen as uneducated. They too were to be 'regenerated'.

In revolutionary France after the fall of Robespierre, critics of the Jacobin citizenship regime of 1792-1794, for example, accused Jacobin terrorists and their supporters of being unenlightened, even 'savage' peoples (see Chapter 5); Batavian revolutionaries could be heard arguing that the 'rabble' needed 'leading reins' (see Chapter 7). ${ }^{36}$ My concern here is not to systematically compare how the discourse of civilizational inequality was applied - or transposed - to various groups. The point rather is that he Haitian Revolution prompted the invocation and politicization of this discourse and led to feelings of disenchantment with 'revolutionary' universalism that became intertwined with and were echoed in domestic regimes of exclusion applied to the 'uncivilized' within. ${ }^{37}$

The notion of inequality in terms of enlightenment or civilizational progress was part of a more general discourse that lay at the heart of French revolutionary political culture. Confronted with the wave of claims and petitions by a range of suppressed social (minority) groups that the inner logic of universalistic language had invited, revolutionaries faced a penetrating question. As Alyssa Goldstein Sepinwall put it: 'How could they create a unified nation out of a country seemingly bursting with diversity - in religion, language,

35 B. Bosch, 'De slaavenhandel', De leerzame praat-al, II, no. 46-48 (November 16, 23, 30, 1791), pp. 361-384. Idem, no. 48, November 30, 1791, p. 384. The next issue of De leerzame praat-al of December 7, 1791, dealt with 'The natural Rights of Man and Citizen'.

36 Baczko, Ending the Terror, pp. 185-223.

37 William Max Nelson has interestingly argued that in late eighteenth-century France 'the new anthropological perspective that emerged in part from the Enlightenment engagement with colonial people and places was refashioned through projects of revolutionary regeneration' and that 'the internal anthropology that took shape during the Revolution and focused on knowing and transforming the French peasantry was linked to the earlier history of external colonization and external ethnography'. See W.M. Nelson, 'Colonizing France. Revolutionary Regeneration and the first French Empire', in: Desan, Hunt, and Nelson (eds.) The French Revolution in Global Perspective, pp. 73-85, at p. 75 . 
wealth, gender, geography, and race?'38 The concept of régénération, formerly a term that only appeared in religious and medical vocabularies, acquired a distinct moral and political meaning at the end of the eighteenth century. Its newly invested meaning was perhaps expressed most clearly in CharlesFrédéric Reinhard's Le néologiste français, ou vocabulaire portative des mots le plus nouveaux, according to which 'régénération' signifies 'an ameliorated reproduction, a physical, moral or political perfection of an object.' ${ }^{39}$

The notion of regeneration, as Mona Ozouf and Antoine de Baecque have pointed out, was a key-concept in French revolutionary political culture. The declaration of the rights of man and citizen occupied a central place in the process of the revolutionary regeneration of man. It ushered in the era of what was sometimes called 'l'homme nouveau'. This blueprint of the 'new man' brought about a dramatic the rupture with the figure of the Old Regime subject. But as the revolution unfolded many revolutionaries struggled with the tension that lay at the heart of the concept of regeneration: if the declaration of the rights of man and citizen had proposed the rebirth of man, why did the reborn man still require regeneration? Ozouf and De Baecque have distinguished two visions of regeneration, one quasi-religious, millenarian view presupposing the sudden 'miracle of a new birth', and another more 'laborious' type of regeneration that requires strict education, coercion and, above all, patience. ${ }^{40}$

Against this background, the idea of a gradual emancipation or régénération of black slaves and non-western peoples into citizens was widely considered to be a commendable course of action throughout the Atlantic world, although the time paths, practical implementation, and the precise nature of such programs varied considerably. Such emancipation programs naturally rested on a (temporary) differentiation of citizenship within the polity. Distinctions were drawn between full, second class, or even more stripped-down notions of citizenship according to the level of civilization of the empire's inhabitants. In response to the Haitian Revolution, when the question of the scope of equal rights and citizenship was posed in such a radical way, this discourse was

38 The formulation of the question is Sepinwall's. Sepinwall, The Abbé Grégoire and the French Revolution, p. 91.

39 C.F. Reinhard, Le Néologiste français, ou vocabulaire portatif des mots le plus nouveaux (Nurnberg: Grattenaver, 1796). As cited in : A. de Baecque, Le corps de l'histoire. Métaphores et politique (1770-180o) (Paris: Calmann-Lévy, 1993), p. 168.

40 De Baecque, Le corps de l'histoire; M. Ozouf, L'homme régénéré: Essais sur la Révolution française (Paris: Gallimard, 1989); See also Ozouf's entrance on 'Regeneration' in: Furet and Ozouf (eds.), A Critical Dictionary of the French Revolution. 
deliberately invoked on a transatlantic scale to delineate one's political community of citizens.

\section{Unity and Hierarchy in the French Empire}

In their address to the French Legislative Assembly in November 1791, a delegation of colonial planters and deputies of Saint-Domingue offered their account of the situation in Saint-Domingue. Unsurprisingly, it was highly coloured. They pictured the actions of the insurgents as 'scenes of African atrocities' and acts of 'barbarism', and painted the gruesome scene of revolting slaves holding 'as a banner the cadaver of a white child impaled upon the end of a pike'. This image, possibly made-up, would be replicated throughout the Atlantic. ${ }^{41}$ The delegates suggested that slaves in the Caribbean were actually better off than when they had stayed in Africa, 'without political existence, without civil existence. This was a mainstay of the proslavery argumentative arsenal. They also praised the 1789 Declaration of the Rights of Man and Citizen. The document was no doubt 'salutary for hommes éclairés (enlightened men)', but inapplicable to slaves who are 'incapable of enjoying their liberty wisely'. ${ }^{2}$ From the moment they set foot on French soil to tell their side of the story, they framed the insurrectionists as unenlightened, dangerous savages who could only be controlled by re-imposing a strict hierarchy governed by 'enlightened men'.

In the following months and years, France saw an outburst of publications of eyewitness accounts of the insurrection, many of which, according to Jeremy Popkin, 'cast the violence in Saint-Domingue as a stark, racialized confrontation between civilized whites and barbaric enemies', although a small number of accounts described the black insurgents in more humane terms. ${ }^{43}$ The main accusation white planter class and their representatives flung at the Société des Amis des Noirs was that they were responsible for the colony's ruin. More or less denying the agency of black insurrectionists, they argued that the philosophical ideas of these 'philanthropists' had spurred black slaves into action.

In their turn, members of the Société des Amis des Noirs accused white planters not only of being stubborn, self-interested conservatives who threatened the survival of the colonial empire, but also of being counterrevolutionaries contesting the nation's supreme and undivided authority. Under the leadership of the prominent Jacobin Brissot, members and former members of the

$41 \quad A P$ 35, p. 461; Dun, Dangerous Neighbors, pp. 56-57.

$42 \quad A P_{35}$, pp. 464-465.

43 Popkin, Facing Racial Revolution, pp. 9, 25. 
Société des Amis des Noirs had become more dominant in the Legislative Assembly, although the society itself fell apart in late 1791 . They eagerly sought to counter the account promulgated by the white planter class, and the tide of public opinion was turning in their favour. A representative example is the speech addressed to the Legislative Assembly on February 29, 1792, by the Parisian lawyer and representative Jean-Philippe Garran-Coulon. Indicative of the change in the climate of opinion that had occurred over the preceding months was that, according to the day-to-day records, Garran-Coulon's speech prompted applause at several moments and motivated a number of deputies to request printed copies of it afterwards (although the speech was actually read in his absence). ${ }^{44}$ Excerpts and fragments of Garran-Coulon's speech were translated into English to be appended to the English abolitionist Thomas Clarkson's An Inquiry into the Causes of the Insurrection of the Negroes in the Island of St. Domingo, which was widely distributed by the Pennsylvania Abolition Society. Garran-Coulon's translated speech even appeared in a series spread over several days in the Philadelphia newspaper Dunlap's American Daily Advertiser in July $1792 .{ }^{45}$

The first view Garran-Coulon set out to rectify was the allegation that the revolt by people of colour and the slave insurrection were products of some 'conspiracy' machinated by the Société des Amis des Noirs and their 'philosophical writings'. Instead, he claimed that it had resulted from the 'perpetual injustice' of slavery and the 'civic degradation' of people of colour. Just 'like the Génevois, Avignonnais, and Liégois, the people of colour wanted to be free', Garran-Coulon argued. But the white planter class had refused to implement the decree of 15 May and chose war. Amidst these bloody scenes, how could

44 'Lecture du discours de M. Garran-de-Coulon' read by M. Guadet. AP 39 (February 29, 1792), pp. 209-220.

45 Garran-Coulon's speech appeared as an appendix to T. Clarkson, An Inquiry into the Causes of the Insurrection of the Negroes in the Island of St. Domingo. To which are added, Observations of M. Garran-Coulon on the same Subject, read in his Absence by M. Guadet, before the National Assembly, 29th Feb. 1792 (London: Johnson, 1792). This pamphlet was distributed by the Pennsylvania Abolition Society and the British Society for Effecting the Abolition of the Slave Trade. For this, see Oldfield, Transatlantic Abolitionism in the Age of Revolution, p. 97. It was printed (spread over seven editions) in the Dunlap's American Daily Advertiser (Philadelphia, Pennsylvania) between 6 and 23 July 1792. It was not the last time that Garran-Coulon would address the situation in Saint-Domingue. In 1797-1798 he would publish a 2000 page long, four-volume report on 'the troubles of Saint-Domingue' on behalf of the Colonial Committee, which modern historians still deem an essential primary source on the Haitian Revolution. J.P. Garran-Coulon, Rapport sur le troubles de Saint-Domingue, fait au nom de la Commission des Colonies, des Comités de Salut Public, de Législation, et de Marine, réunis, 4 vols. (Paris: Imprimerie nationale, An V [1797-1798]). 
the negroes not reflect on their extreme misery and intolerable debasement, on their incontestable rights and formidable number, and on the divisions between their masters?', Garran-Coulon asked. The only ones responsible for the revolt were the French planters themselves, the men who were 'accustomed to despise their fellow men' and 'hold them in most brutal slavery'. By refusing to implement the decree of May 1791 the white planters in Garran-Coulon's eyes essentially had put limits to the sovereignty of the nation, by contesting its supremacy and unity'.46

After all, 'did not the same colonial deputies and their audacious partisans utter everywhere the threat of separation like a spectre, while boasting the example of the United States?'47 But Garran-Coulon turned the parallel that was sometimes drawn between white settlers claiming colonial independence for Saint-Domingue and their bigger New World neighbour's struggle for independence upside down. In a clever rhetorical stroke, repeating a denunciation against the planters that was filed earlier in December 1791 by Brissot, GarranCoulon identified the deeds of white planters as a 'counterrevolution' undertaken by 'antipatriotic confederations' formed at the island. ${ }^{48}$ Above all, he insisted that

the disastrous effects of so much weakness, and of the omission of all principles upon which our liberty is based, must teach us a lesson. They show us simultaneously the cause of the tragedy of Saint-Domingue and the appropriate measures to solve it. They teach us that we never ought to allow any infringements to be made on the national sovereignty, and even less still on the eternal rights of nature and reason; that palliatives can no longer be used; that the lack of energy on our part will perpetuate the misfortunes of the colonies; that it will consume the white planters themselves, as they persist in foolish preservation of their pride up to the point of their complete destruction; that, finally, all the authority the nation has handed down to us is to be exerted in order to save [the colonies] despite of themselves, and naturalize in these lands, if for a long time defiled by the violation of all rights of humanity, the great principles of justice, which must henceforth be inseparable from the French law. ${ }^{49}$

46 Garran-Coulon, 'Lecture', $A P$ 39, pp. 210-211, 216.

47 Garran-Coulon, 'Lecture', $A P$ 39, p. 211.

48 Ibid.

49 Ibid., p. 212. 
The risk of colonial secession, then, imperilled not only France's economic interests and symbolic power as an Atlantic empire, but also thwarted the endeavours of such prominent revolutionaries as Brissot, Condorcet, the Abbé Grégoire, and Garran-Coulon. They attempted to carry through what they saw as a universal revolutionary project, a project which proclaimed within the French empire civic and political equality to all free men regardless of their colour. In that sense, the ways in which revolutionary discourse was put to use by, on the one hand, North American revolutionaries during the 1770s and 178 os and, on the other hand, egalitarian French revolutionaries during the 179os, had reversed. Whereas American revolutionaries had fought a righteous cause, invoking the notions of the rights of man and national sovereignty so as to legitimize their break-up from the British Empire, French revolutionaries like Garran-Coulon invoked the rights of man in order to keep Saint-Domingue within the French empire so as to guarantee the constitutional unity of one political community.

Those who deployed this logic of an indivisible universal empire ignored the de facto hierarchical subordination of potentially self-determining political communities (within the empire). From Garran-Coulon's point of view this was unproblematic, since 'the incorporation of diverse parts of the Empire and the duration of the social contract' have for both these integrated parts and for individuals 'a solid and just foundation in common utility'. American independence and the French model of imperial assimilation were two sides of the same coin:

The American Revolution and ours [...] are only the forerunners of a universal renovation of all political institutions, are already dedicated to this great principle: the one through its separation from the mother country, the other through the decrees on Alsace, the abolition of privilege in all provinces, and through the access of the state Avignon into the realm. ${ }^{50}$

For Garran-Coulon and his allies there was no conflict between universalism and imperial assimilation, whether in the case of Alsace, Avignon, or Saint-Domingue.

Garran-Coulon thus made the case that order in the colonies could only be restored, and moreover, the promise of the rights of man and citizen could only be fulfilled, through the interventions and efforts of a metropolitan-based political elite. This strategy was premised on the idea that the colonies are 'expressément part of the French empire, and consequently, of the nation'. An

Garran-Coulon, 'Lecture', $A P$ 39, p. 213. 
'enlightened nation', after all, 'invests her ambition more in the propagation of principles than in the extension of her power. ${ }^{51}$ In line with the great French tradition of bombastic revolutionary rhetoric, Garran-Coulon called upon his colleagues to 'expand the empire of liberty and justice' and invited everyone 'to join us to contemplate in the temple of equality over the means to assure the happiness and liberty of all members of the French empire..52

Despite this universalist rhetoric, Garran-Coulon and his fellow ex-Amis des Noirs maintained that a French constitutionally unified empire should be governed by a civilizational hierarchy. In their view, the task, or as it would be called in the nineteenth century, the 'mission civilisatrice', was to ameliorate the condition of slaves and regenerating the 'uncivilized' so as to make them fit for republican citizenship. This task was best secured in the hands of a metropolitian based political elite at the centre of power. ${ }^{53}$

The lesson drawn from the opposition of Saint-Domingue colonial political elites to granting free men of colour equal rights made abundantly clear that this task could not be entrusted to them. Accordingly, as Marcel Dorigny has rightly underscored, the 'doctrine' of the Société des Amis des Noirs was abolitionist, but by no means 'anti-colonialist' (as we will see, this applies to Dutch antislavery revolutionaries too).${ }^{54}$ Instead, their agenda consisted of a redefinition of the notion of citizenship within the framework of a colonial (and from August 1792 onward: 'republican') empire. It did not imply a first step from Atlantic empire to nation-state. It was, rather, an attempt to make the French empire compatible with the ideals of the French revolution.

This vision was concisely summarized by Antoine-Jean-Thomas Bonnemain in his pamphlet Régénération des colonies published in March 1792: 'According to the declaration of the rights of man, all individuals that constitute the empire must be citizens; their rights are guaranteed by the constitution'.55 But he immediately added that this eternal principle cannot for the moment be

$51 \quad$ Garran-Coulon, 'Lecture', $A P$ 39, p. 214.

52 Ibid., p. 213.

53 On the inellectual background of this 'mission civilisatrice', see P. Røge, 'l'Économie politique en France et les origines intellectuelles de 'la mission civilisatrice' en Afrique', Dixhuitième siècle 44 (2012), pp. 117-130.

54 M. Dorigny, 'La société des amis des noirs et les projets de colonisation en Afrique', Annales historiques de la Révolution française 293-294 (1993), pp. 421-429; M. Dorigny, 'Intégration républicaine des colonies et projets de colonisation de l'Afrique: Civiliser pour émanciper?', in: Dorigny and Bénot (eds.) Grégoire et la cause des noirs, 1789-1831, pp. 89107. Cf. F. Gauthier, [review] Yves Bénot, 'La Révolution française et la fin des colonies', Annales historiques de la Révolution française 271 (1988), pp. 491-493.

Bonnemain, Régénération des colonies, pp. 95-96. 
applicable [...] to persons that are not at liberty.56 Bonnemain's pamphlet had been successfully blocked by the white planter lobby in Paris for two years. In the supplement Bonnemain added to the 1792 publication addressing the current situation, he explicated that 'unfree people' ought to be considered as 'minors under the tutelage of the government'. The law should only gradually improve their 'civil and political state'. ${ }^{57}$

Such visions of the French empire had been articulated earlier by amongst others Condorcet and Henri Grégoire. ${ }^{58}$ They revealed not only a 'new' civilizational hierarchy but also a program of what Bonnemain called 'la régénération de l'espèce humaine. The basic belief was that black slaves due to their uncivilized and unenlightened mental and moral condition were not yet eligible for the duties and rights that come with modern citizenship. They had to be 'regenerated' in order to be admitted to a uniform civic community. Bonnemain's Régénération des colonies too passionately defended the decree 'to accord [...] the quality of citizen' to Saint-Domingue's free people of colour. In the same breath, however, he proposed to '[s] uppress the shameful name slave, [and] replace it'. Not by the title of citizen, but by 'the interesting name of pupil'. ${ }^{59}$

The Société des Amis des Noirs was incessantly accused of inciting the rebellion, mostly by conservatives and spokesmen of the planter's class. But radical revolutionaries who were overall sympathetic to the aims of the Société des Amis des Noirs too could be heard expressing feelings of disenchantment in the wake of the slave insurrection. ${ }^{60}$ The reaction of the renowned defender of both women's, coloured and black people's rights Olympe de Gouges, for instance, unambiguously depicted the black insurgents' acts as 'savagery'. In a new preface written in 1792 to her theatre play L'esclavage des noirs ou l'heureux naufrage (Black Slavery, or the Happy Shipwreck), which was originally staged in 1789 , De Gouges's response to the slave insurrection was imbued with a sense of disappointment. Explicitly addressing black slaves and men of colour, she lamented that 'Men were not born in chains, yet you prove that they are necessary'. ${ }^{61}$ Praising 'social order' and the 'wisdom of law', De Gouges warned that 'if the savage, a ferocious man, fails to recognize this Law, then he is made

$56 \quad$ Bonnemain, Régénération des colonies, p. 77.

57 Bonnemain, 'Supplement', in: Régénération des colonies, pp. 104-105.

$5^{8}$ M. Schwartz [Condorcet], Réflexions sur l'esclavage des nègres (Neufchâtel: Société typographique, 1781); Sepinwall, The Abbé Grégoire and the French Revolution, p. 96.

59 Bonnemain, Régénération des colonies, p. 77 (italic in original).

6o Cf. Dubois, Avengers of the New World, pp. 105-106.

61 O. de Gouges, L'esclavage des noirs, ou l'heureux naufrage (Paris: Duchesse, 1792). Translation taken from 'Preface' to The Slavery of Blacks, in: Dubois and Garrigus (eds.), Slave Revolution in the Caribbean, p. 109. 
for irons, to be tamed like a brute'. De Gouges's cautious hope that her France, 'an enlightened nation', 'was not mistaken to treat you like men and give you rights that you never had in America' echoed the Abbé Grégoire's earlier rendering of the extension of 'universal' rights to free people of colour as a gift from the enlightened mother country to the oppressed man. This precious gift could be taken away if they did not live up to the expectations of an 'enlightened nation'.

Such reflections show that the Société des Amis des Noirs and other advocates of gradual abolition in revolutionary France were caught up by events. Their interventionist strategy granting free people of colour equal rights as the only viable course of action to contain and put an end to the slave revolt in the end carried the day. But it was accompanied by a series of restatements that black slaves were not eligible for citizenship in an empire that they so passionately defended as a constitutionally unified polity.

The image of a once wealthy and orderly colony racked by horrific violence and devastation also came to dominate American media. ${ }^{62}$ The reports, oral communications, and refugees coming from Saint-Domingue between late 1791 and 1794 arrived at a critical transitional stage in the emergence of rival interpretations of the French Revolution. Whereas initially the American public generally interpreted the French Revolution as a confirmation of their own revolution, the king's flight to Varenne in June 1791, his deposition and the founding of the French Republic in August and September 1792, the September massacres, the execution of Louis XVI in January 1793, the declaration of war against Britain the following month, and the coming of the Terror generated highly politicized and conflicting interpretations of the course the French Revolution had taken.

Democratically-minded Americans, dissatisfied with what was in their view still a system of elite politics, welcomed the egalitarian spirit of the French Revolution as heralding a new phase in the unfinished transformation of

62 The stream of literary representations of the 'horrors of Saint-Domingue', as Matt Clavin has argued in a fascinating article, also contained elements of sensationalism and entertainment, 'blurring the line of fiction and nonfiction', and drawing on the popular Gothic genre that authors and publisher tried to exploit in a 'competitive literary marketplace'. M.J. Clavin, 'Race, Revolution, and the Sublime: The Gothicization of the Haitian Revolution in the New Republic and Atlantic World', Early American Studies: An Interdisciplinary Journal 5 (2007), pp. 1-29. 
American politics and society. In their eyes, there were still remaining aristocratic elements to be eliminated; the American Revolution was not finished, its promises not yet fulfilled. Federalists, on the other hand, conscious that the new American Republic was in many ways a fragile experiment, wanted the constitution to be a framework for harmonious government and a bulwark against popular democracy. ${ }^{63}$ Although for a time Federalists were sympathetic to a revolution that reminded them so much of their own, they soon came to follow the outburst of domestic popular enthusiasm for the more democratic 'sister republic' with growing concern. Well before news of the Terror would reach the shores of the American Republic, Federalists already nourished a deep suspicion of the democratic forces the French Revolution seemed to unleash.

While American reflection on both Saint-Domingue and the Terror took place within the context of an emerging political partisanship between Federalists and Republicans, it is important to realize that the very notion of partisanship, opposition or faction, ran counter to deeply held ideals of an undivided political body and the belief in one identifiable common good. ${ }^{64}$ The quarrels between Federalists and anti-Federalists in the second half of the 178 os over the ratification of the new constitution were hardly compatible with the Federalist ideal of an orderly and united republic. Hence there was a strong desire that the newly accepted constitution would announce - and come to symbolize - a definite closure of a political culture of public disagreement and civic conflict. Yet the opposite happened. Already in 1790, discontented Virginian politicians, most prominently the congressional leader James Madison and Secretary of State Thomas Jefferson, began to oppose Secretary of the Treasury Alexander Hamilton's program of centralized state building and strengthening of the national government. Hamilton's financial proposals for the establishment of a national bank and for the federal government's assumption of the debts of individual states would in the eyes of Jefferson and Hamilton unduly favour the northern states and their commercial interests. Their opposition to Hamilton's policies and the government administration led to the formation of a loose coalition of likeminded critics that would come to be known as 'Republicans'. Initially, Republicans had their stronghold in southern states, an

63 W. Holton, Unruly Americans and the Origins of the Constitution (New York, N.Y.: Hill and Wang, 2007); T. Bouton, Taming Democracy: 'The People', the Founders, and the Troubled Ending of the American Revolution (Oxford: Oxford University Press, 2007).

64 J.R. Sharp, American Politics in the Early Republic: The New Nation in Crisis (New Haven, CT:Yale University Press, 1993), pp. 8-10. See also, R. Hofstadter, The Idea of a Party System. The Rise of Legitimate Opposition in the United States, 1780-1840 (Berkeley, CA: University of California Press, 1972), pp. 40-73. 
overwhelmingly rural world that depended economically on plantations making use of black slave labour. Southern Republicans opposed the vision of a strong, centralized government, and cherished the ideal of the independent, rural, landowning (white male) citizen. Over the course of the 1790s, however, in the northern states the popular anti-establishment rhetoric of the Republican opposition came to attract increasing numbers of yeoman farmers and ambitious urban middleclass people discontent with Federalist elites. ${ }^{65}$

The supporters of the national government's policies were known as the 'Federalists', a label that was appropriated from those who advocated a national constitution in the late 178 os. The Federalists had their stronghold in the more urbanized northern states that were economically based on trade and commerce. ${ }^{66}$ The Federalist persuasion was much more steeped in a deferential and hierarchical vision of politics: a strong centralized bureaucratic government ought to be in the hands of elites at a distance from ordinary citizens and public opinion. They were regularly accused by Republicans of being monarchists in disguise, intent on setting up a monarchical government modelled on England and betraying the principles of the revolutionary republicanism of the 1770 . Federalists, in turn, saw Republicans as popular agitators and unruly democrats. Neither were organized like modern, political parties. Rather, as historian James R. Sharp put it, 'these designations were generic terms of advocacy, public labels that signalled endorsement of certain principles'. ${ }^{67}$ News of the events in Saint-Domingue would arrive in this increasingly polarized public sphere and political climate.

American newspapers of late 1791 and early 1792 typically related of 'acts of most shocking cruelty', 'the cruelty of savages', and 'barbarous massacres'. 68 The Boston leading Federalist newspaper Columbian Centinel, reproduced the image of the 'standard borne by the insurgents [...] a white child impaled upon

65 J.O. Appleby, Capitalism and a New Social Order: The Republican Vision of the 1790 (New York: New York University Press, 1984); L. Banning, The Jeffersonian Persuasion: Evolution of a Party Ideology (Ithaca, N.Y.: Cornell University Press, 1978); R. Buel, Securing the Revolution. Ideology in American Politics, 1789-1815 (Ithaca N.Y.: Cornell University Press, 1972).

66 Buel, Securing the Revolution. Although the Federalists had their stronghold in northern states and Republicans in southern states, national politics was not sharply divided between a Federalist commercial North (or New England) and a republican agrarian South. There were numerous mercantile Republicans in the North and agrarian Federalists in the South.

67 Sharp, American Politics in the Early Republic, p. 9.

68 The New-York Journal, \& Patriotic Register (New York, New York), September 28, 1791; The New-York Journal, \& Patriotic Register (New York, New York), October 15, 1791; Claypoole's Daily Advertiser (Philadelphia, Pennsylvania), January 2, 1792. 
a pike, a piece of barbarity worthy of such savages'.69 Admittedly, sporadic comments American newspapers omitted or toned down the alleged savagery and instead highlighted the injustice of slavery, the motives for insurrection, or the remedies to put the disturbances to an end. One New York newspaper, for instance, contended that the exclusion of free people of colour and free blacks from citizenship was in fact 'one of the causes of the disturbances in that unfortunate colony', and that the solution to the troubles should at any rate consist of 'a re-election of the colonial and other popular assemblies of the island, in which free people of colour and negroes will have voices.' ${ }^{70}$

Yet on the whole, the general picture of the island was bleak. From within Saint-Domingue, Nathaniel Cutting anticipated in one of his many letters to Secretary of State Jefferson that news 'of the horrid devastation' had probably already reached him. ${ }^{71}$ Cutting's letters to Jefferson, many of which were circulated in government circles and some of which were printed (and copied) in several newspapers, testify to the shifting appraisal of revolutionary France in light of the events of Saint-Domingue. Cutting supposed that the colonial 'French Aristocrates' [sic] who were hoping for a counterrevolution in France could be partly held responsible for the colony's ruin, accusing them of being 'stimulators and abettors of all the horrid proceedings'. But on a more ideological level, Cutting attributed the chaos and anarchy to the excrescences of the 'leveling [sic] principles' of revolutionaries 'in France \& elsewhere'. The 'infernal transactions' that were taking place on the island, Cutting suggested, 'are only the ebullitions of uncultivated spirits which have made a sudden transition from the extreme of ignorance and despotic restraint, to certain mistaken ideas of the Rights of Man and that unbridled licentiousness consequent thereto'. ${ }^{72}$ In a subsequent letter dated April 13, 1792, that would be printed in the (Republican) National Gazette and the New-Jersey Journal, Cutting averred that the island's free people of colour and black slaves were infected by 'specious opinions [...] which have been so industriously disseminated by some impolitic pretenders to philanthropy' ${ }^{73}$ Such allegations laid the building blocks for the view that French 'levelling principles' were wrongly and naively

69 Columbian Centinel (Boston, Massachusetts), February 18, 1792.

$70 \quad$ The Diary or Loudon's Register (New York, New York), October 11, 1792.

71 Cutting to Jefferson, 29 November 1791, PTJ.

72 Nathaniel Cutting to Thomas Jefferson, 28 December 1791, PTJ; Cutting, Journal, 1 December 1791, as cited in: Newman, 'American Political Culture and the French and Haitian Revolutions', p. 79.

73 Cutting to Jefferson, 13 April 1792, PTJ. The letter appeared in the National Gazette (Philadelphia, Pennsylvania) of May 7,1792 , and the New-Jersey Journal (Elizabethtown, New Jersey) of May 16, 1792. 
applied to a population that was portrayed as too 'uncultivated' for emancipation.

Similar to the accounts of Paulus and Kluit, one of the common tropes used in American newspapers to describe the lack of civil order in Saint-Domingue was 'anarchy' - often in combination with the notion of a 'return' to a state of 'wilderness'. Some of these comments displayed a similar reasoning that such 'savages' were not to be emancipated immediately. As an article in the New York Daily Advertiser put it: 'Brutal and savage men know no medium between the most abject slavery and the most licentious tyranny. The emancipation of slavery in the West Indies should be gradual, just as it was in Europe - where it was accomplished by the progressive influence of religion, humanity, and commerce, rightly understood. ${ }^{74}$ Cutting added his voice to this choir, writing that the 'bloody Banner of Anarchy' will 'long continue display'd' if the insurgents whom he regularly described as 'savage banditti' or 'remorseless savages', would not be crushed. ${ }^{75}$ It only strengthened the preconceived conceptions of slaveholding men such as Jefferson. In a letter to his daughter Martha predating the 1791 insurrection, Jefferson had sounded a similar theme, writing that the islands in the West Indies, 'most particularly St. Domingue and Martinique', were involved in a 'horrid civil war' and that the inhabitant's slaves were 'absolutely ungovernable. ${ }^{76}$

Such responses to this phase of the Haitian Revolution coincided with and mutually invigorated the initial responses to news of the radicalization and violence of the French Revolution. From late 1792 onwards, American newspapers of mostly but by no means exclusively Federalist signature began to report 'excesses' in Paris springing from the 'rage of the populace. ${ }^{77}$ Readers of both the Republican National Gazette, and the more Federalist-leaning Connecticut Journal and New-Hampshire Gazette, learned that the 'fatal 2d of September' was the work of a 'sanguinary mob'. ${ }^{78}$ Such alarming news from France made many Americans aware that the French Revolution had entered a new phase. 'This country continues to be drenched in blood', a comment printed in (both Federalist and Republican) Massachusetts and Vermont newspapers stated in November 1792. 'And the genius of this once polished people, seems to suffer a

74 The Daily Advertiser (New York, New York), January 19, 1792.

75 Cutting to Jefferson, 21 January 1792, PTJ; Cutting to Jefferson, 1 March 1792, PTJ.

76 Jefferson to Martha Jefferson Randolph, 24 March 1791, PTJ.

77 The North-Carolina Journal (Halifax, North Carolina), November 28, 1792.

78 National Gazette (Philadelphia, Pennsylvania), November 14, 1792; Connecticut Journal (New Haven, Connecticut), November 14, 1792; New-Hampshire Gazette (Portsmouth, New Hampshire), November 21, 1792 . 
gradual deterioration; their cruelty exceeds belief, and they every day give new and shocking proofs of their ingenious barbarity.' ${ }^{79}$

The theme of mob violence figured prominently in these first comments, but those favourably disposed to France's revolution believed it to be a lamentable but necessary means to achieve a greater cause that was connected to their domestic situation. In late December 1792, for example, the National Gazette, the foremost Republican newspaper of the early 179os set up by Madison and Jefferson in 1791 to reach a nationwide audience, attacked the Federalist Vice-President John Adams for recommending 'hereditary monarchy' and 'aristocracy'. In the same article, it praised French Jacobins for loosing 'the shackles of slavery of thirty millions of people' and for contributing to the 'emancipation of the human race. ${ }^{80}$ In June 1793, the same National Gazette, as well as the more radical-democratic Boston Argus, printed the series of articles (spread over several issues) 'Cool Reflections relative to the French Revolution' by 'Philadelphus'. The author (National Gazette's editor Philip Freneau himself, according to the Boston Argus), urged 'every American to consider the struggles of France as a continuation of the glorious struggles of his own country'. The dethronement of Louis XVI on August 10, 1792, although 'attended with violence, convulsion and blood' and although it could 'easily be disfigured into a picture of horror, and a sad example of popular government' was 'a necessary and wise, as well as a justifiable measure. ${ }^{81}$ The revolutionary violence was, thus, interpreted as an aberration, not as an essential outcome of political principles or the lack of moral uprightness on the part of the French people. As one New Jersey newspaper lamented: 'some horrid cruelties have been perpetrated, by lawless and savage mobs [...] which none but aristocrats and monarchical men will dare to impute to the French as a Nation'.82

In these feuds over the assessment of revolutionary France, Saint-Domingue became another battleground for the evaluation of French universalism and popular violence. Thomas Paine's Rights of Man offered a vocabulary to reshape antislavery discourse into a trans-Atlantic struggle against oppression. 'Nature gave the African rights, of which he cannot be divested without an act of injustice', 'A Friend to the Rights of Man' proclaiming to be living in an

79 Western Star (Stockbridge, Massachusetts), November 20, 1792; Vermont Gazette (Bennington, Vermont), November 30, 1792.

8o National Gazette (Philadelphia, Pennsylvania) December 26, 1792.

81 The Argus (Boston, Massachusetts), June 18, 25, 26, 1793. National Gazette (Philadelphia, Pennsylvania), June 5, 8, 19, 22, 1793. The Argus identified the National Gazette's editor-inchief Philip Freneau as the author of the articles.

82 The New-Jersey Journal (Elizabethtown, New Jersey), May 8, 1793. 
'enlightened age' wrote in the National Gazette. ${ }^{83}$ Other voices, such as the lawyer and publicist Theodore Dwight, justified the violence on Saint-Domingue in a way similar to the justifications that were given for the violence in the French metropole. In an oration for the Connecticut Abolition Society, Dwight called upon his fellow citizens to turn their attention to Saint-Domingue, where 'ideas of freedom and slavery' had 'taken stronghold of the negroes'. Dwight felt no need for concealing the 'desolation and blood over the face of the colony'. He implied, however, that such evils 'necessarily attend such convulsions of liberty' and are inevitable in order for the insurgents to establish themselves 'on the firm pillars of freedom and independence'. ${ }^{84}$ These antislavery radicals such as Dwight, Abraham Bishop (Chapter 2), or the Kentucky Presbyterian minister David Rice, however marginal, called out for solidarity with the black insurgents and advocated a model of equal citizenship, embedding it in a trans-Atlantic revolutionary context.

On the proslavery end of the spectrum, responses to the slave insurrection were shot through with an increasing abhorrence and consequently a rejection of what was seen as 'French' philosophical radicalism. Condemnations of, and dissociations from, what was often depicted as a French 'experiment' in the colonies became widespread. 'In fact', one South-Carolina commentator stated, 'Brissot and his factious friends in the convention [...] certainly are the principal authors of all the horrors committed in St. Domingo', ${ }^{85}$ American newspapers from slaveholding states printed virulent op-ed articles relating 'Jacobin' radicalism to the civic emancipation of black and coloured people. Particularly telling is a piece in Charleston's Columbian Herald or the Southern Star of December 5, 1793, written by someone under the pseudonym 'MONITOR'. The author indicted the Second Civil Commission that had landed in Cap Français in September 1792 and were originally instructed to enforce the decree of April 4, 1792, but eventually issued a proclamation of general emancipation that included black slaves in August 1793. These 'agents, who now support and decorate the French system',

are the favorites and followers of Danton, Robespierre, Brissot, and Marat [...] Sonthonax, Polverel, and other emissaries received their mission from their Jacobin creators - Go said their masters [...] Subject the world

$83 \quad$ National Gazette (Philadelphia, Pennsylvania), December 26, 1792. This op-ed article was copied from the Augusta Chronicle.

84 T. Dwight, An Oration, spoken before the Connecticut Society, for the Promotion of Freedom and the Relief of Persons unlawfully holden in Bondage (Hartford, CT: Hudson and Goodwin, 1794). See also Abraham Bishop's series of articles discussed earlier (n. 11).

85 The City Gazette \& Daily Advertiser (Charleston, South Carolina), November 26, 1793. 
to the Jacobins of France [...] we give you the secret of revolution and the spoils of devastation [...] sow dissention \& create discord [...] and bring those of desperate fortunes, mobs and others, with the charms of promised equality. [...] The massacre being over, the city burnt, the plate and monies collected for the service of the republic, the business done, your mission is fulfilled, sing ca ira, Vive la Republique. ${ }^{86}$

Such commentators looked upon the Jacobins' 'charming' promise of equality with fear. As Thomas Jefferson wrote to then Senator James Monroe in the Summer of 1793, he was becoming 'more and more convinced that all the West India islands will remain in the hands of the people of colour, and a total expulsion of the whites sooner or later take place'. It was 'high time we should foresee the bloody scenes which our children certainly, and possibly ourselves $[\ldots]$ have to wade through, and try to avert them.87 ${ }^{8}$ Such evaluations stood at the basis of a conclusion that would gradually replace the initial expressions of cosmopolitan enthusiasm and feelings of universal brotherhood: the French revolutionary project of citizen emancipation was at odds with theirs.

86 Columbian Herald or the Southern Star (Charleston, South Carolina) of December 5, 1793. Abstracts of the proclamation had appeared in, among others, The Federal Gazette and Philadelphia Daily Advertiser (Philadelphia, Pennsylvania), October 15, 1793.

87 Jefferson to James Monroe, July 14, 1793, PTJ. 